Chirurg 2020 91 (Suppl 1):S13-S14 https://doi.org/10.1007/s00104-020-01152-4 Online publiziert: 16. März 2020

(c) Der/die Autor(en) 2020

Beat Müller-Stich - Thomas Schmidt · Henrik Nienhüser · Felix Nickel • Adrian Billeter · Markus Diener · Alexis Ulrich · Markus W. Büchler

Klinik für Allgemein-, Viszeral- und Transplantationschirurgie, Universitätsklinikum Heidelberg, Heidelberg, Deutschland

\title{
Total-minimalinvasive Ösophagektomie
}

\section{Video online}

Die Onlineversion dieses Beitrags (https://doi. org/10.1007/s00104-020-01152-4) enthält ein Video zum Thema "Total-minimalinvasive Ösophagektomie". Beitrag und Zusatzmaterial stehen Ihnen im elektronischen Volltextarchiv auf http://www.springermedizin.de/derchirurg zur Verfügung. Sie finden das Zusatzmaterial am Beitragsende unter "Supplementary Material".

Das Video zum Thema „Total-minimalinvasive Ösophagektomie“ zeigt die Linearstaplertechnik am Beispiel einer 70-jährigen Patientin mit einem Adenokarzinom des ösophagogastralen Übergangs Typ II (Video).

\section{Korrespondenzadresse}

\section{Prof. Dr. Beat Müller-Stich}

Klinik für Allgemein-, Viszeral- und

Transplantationschirurgie, Universitätsklinikum Heidelberg

Im Neuenheimer Feld, 69120 Heidelberg,

Deutschland

Beat.Mueller@med.uni-heidelberg.de

Funding. Open Access funding provided by Projekt DEAL.

\section{Einhaltung ethischer Richtlinien}

Interessenkonflikt. B. Müller-Stich, T.Schmidt, H. Nienhüser, F. Nickel, A. Billeter, M. Diener, A. Ulrich und M.W. Büchler geben an, dass kein Interessenkonflikt besteht.

Für diesen Beitrag wurden von den Autoren keine Studien an Menschen oder Tieren durchgeführt. Für die aufgeführten Studien gelten die jeweils dort angegebenen ethischen Richtlinien. Für Bildmaterial oder anderweitige Angaben innerhalb des Manuskripts, über die Patienten zu identifizieren sind, liegt von ihnen und/oder ihren gesetzlichen Vertretern eine schriftliche Einwilligung vor.

Open Access. Dieser Artikel wird unter der Creative Commons Namensnennung 4.0 International Lizenz veröffentlicht, welche die Nutzung, Vervielfältigung, Bearbeitung, Verbreitung und Wiedergabe in jeglichem Medium und Format erlaubt, sofern Sie den/die ursprünglichen Autor(en) und die Quelle ordnungsgemäß nennen, einen Link zur Creative Commons Lizenz beifügen und angeben, ob Änderungen vorgenommen wurden.

Die in diesem Artikel enthaltenen Bilder und sonstiges Drittmaterial unterliegen ebenfalls der genannten Creative Commons Lizenz, sofern sich aus der Abbildungslegende nichts anderes ergibt. Sofern das betreffende Material nicht unter der genannten Creative Commons Lizenz steht und die betreffende Handlung nicht nach gesetzlichen Vorschriften erlaubt ist, ist für die oben aufgeführten Weiterverwendungen des Materials die Einwilligung des jeweiligen Rechteinhabers einzuholen.

Weitere Details zur Lizenz entnehmen Sie bitte der Lizenzinformation auf http://creativecommons.org/ licenses/by/4.0/deed.de. 
Chirurg 2020 - 91 (Suppl 1):S13-S14 https://doi.org/10.1007/s00104-020-01152-4

(c) Der/die Autor(en) 2020

B. Müller-Stich · T. Schmidt · H. Nienhüser · F. Nickel · A. Billeter · M. Diener · A. Ulrich · M. W. Büchler

\section{Total-minimalinvasive Ösophagektomie}

\section{Zusammenfassung}

Hintergrund. Die onkologische Ösophagektomie ist mit hoher Morbidität verbunden. Mit minimal invasiven Operationsverfahren ist verschiedentlich versucht worden, diese zu reduzieren. Hauptproblem ist dabei die intrathorakale Anastomose. Es existieren verschiedene Techniken, mit dem Problem umzugehen, wie die Anlage einer funktionell problematischen zervikalen Anastomose, die offene Anlage der thorakalen Anastomose (Hybrid-Technik) oder die robotergestützte Anlage der technisch sehr anspruchsvollen Zirkularstapleranastomose. Als minimal invasiv auch ohne Roboterassistenz relativ einfach machbare Alternative zeigen wir die intratho- rakale Seit-zu-Seit Ösophagogastrostomie in Linearstapler-Technik.

Operationstechnik. Der abdominelle Teil erfolgt in French-Lagerung. Nach Dissektion des Omentum majus entlang der gastroepiploischen Arkade und des Milzhilus sowie Trennung des Omentum minus $6 \mathrm{~cm}$ präpylorisch wird ein 4,5 $\mathrm{cm}$ breiter Magenschlauch in Linearstaplertechnik gebildet. Dann erfolgt die systematische abdominale und transmediastinale Lymphadenekotmie. Nach Umlagerung des Patienten in Links-Seitenlage wird die Lymphadenektomie thorakal komplettiert und das Präparat entfernt. Die Seit-zu-Seit Ösophagogastrostomie beginnt mit der Inzision des Ösophagusstumpfes. Dann wird der Magenschlauch mesonah $5 \mathrm{~cm}$ vom oralen Absetzungsrand inzidiert und ein Linearstapler über $3 \mathrm{~cm}$ in die beiden Inzisionen eingebracht und abgefeuert. Die verbleibende Öffnung wird mit einer fortlaufenden Naht modifiziert zweireihig quer verschlossen.

Diskussion. Die Seit-zu-Seit Ösophagogastrostomie in Linearstapler-Technik scheint eine einfache und sichere Alternative für die Rekonstruktion nach minimal invasiver Ösophagektomie zu sein. Die Methode wird aktuell in einer randomisiert kontrollierten Studie untersucht.

\section{Total minimally invasive esophagectomy}

\section{Abstract}

Introduction. Esophagectomy for oncological reasons is associated with high morbidity, which was intended to be reduced by a minimally invasive approach. Main problem of the minimally invasive approach is the challenge of a safe intrathoracic anastomosis. To address this problem several methods such as a collar anastomosis instead of an intrathoracic anastomosis with poor functional outcome, hybrid techniques with an open approach to the demanding intrathoracic circular stapled anastomosis ore robotic assistance have been used. We demonstrate the minimally invasive linear stapler technique for the intrathoracic esophagogastrostomy, which can be applied quite easily even without robotic assistance. Surgical technique. The abdominal part is performed with the patient in French position. After division of the greater omentum along the gastroepiploic arcade and the spleen as well as the perigastric incision of the lesser omentum $6 \mathrm{~cm}$ from the pylorus a $4,5 \mathrm{~cm}$ gastric conduit is created in linear stapler technique. Next an intraabdominal and transhiatal systematic lymphadenectomy is performed. For the thoracic part the patient is repositioned in a left side position. The thoracic lymphadenectomy is completed, and the specimen removed via mini-thoracotomy. For the anastomosis the esophageal stump is incised, and the gastric conduit is opened $5 \mathrm{~cm}$ from the oral resection line. Once the stapler is fired and removed the remaining opening is hand-sewn in a modified doublelayer technique.

Discussion. The side-to-side esophagogastrostomy in linear stapler technique seems to be a quite easily feasible and safe alternative for the reconstruction after minimally invasive esophagectomy. To confirm this, the method is currently investigated in a randomized controlled trial. 